\title{
Poverty Pang in Marine Fishing Communities in the State Of A.P.: A Case Study at Vodarevu Marine Fishing Community in Prakasam District
}

\author{
M. Jaya Kumar Jacob ${ }^{1 *}$ and P. Brahmaji Rao ${ }^{2}$ \\ ${ }^{1}$ Department of Humanities \& Basic Sciences, Chirala Engineering College, Prakasam District, Chirala 523157, Andhra Pradesh, India \\ ${ }^{2}$ Department of Environmental Sciences, Acharya Nagarjuna University, Nagarjuna Nagar, Guntur 522510, Andhra Pradesh, India
}

\begin{abstract}
Received: August 31, 2016; Accepted: November 14, 2016; Published: November 17, 2016
*Corresponding author: M. Jaya Kumar Jacob, Department of Humanities \& Basic Sciences, Chirala Engineering College, Prakasam District, Chirala 523157, Andhra Pradesh, India. E-mail: mjayakumarjacob@gmail.com
\end{abstract}

\begin{abstract}
Marine fishing communities in recently separated state of Andhra Pradesh are facing a severe poverty problem. Extended fish ban and lean period as well as governmental untimely assistance are the main causes of present poverty problem in the marine fishing. The State as well as Central Government was not in a position to release the promised funds to the marine fishing communities in the state of Andhra Pradesh especially to the Prakasam District. Year by year downfall of fisheries is recorded in the study area due to the indiscriminate and unstructured fishing practices at the coast. The poverty alleviation programmes of both the GOs \& NGOs are either nominal or temporary or non-functional due to the short sightedness, growing disparities among the fishing communities based on the gears that were used, ultimately leading to the depletion of fish by overfishing in the study area. Discrimination in budget allocation to the vulnerable as well as disaster proven regions of the country is one of the major problems in India. Poverty is prevailing in the Vodarevu village, directly or indirectly leading to many other problems like pollution, improper sanitation, crime rate, unemployment, depression and debt. The lived experience of marine fishing village i.e. Vodarevu community at Prakasam district in Andhra Pradesh reveals that the politically driven welfare policies of Governments are working towards the country's economic growth rather than to safeguard the fishermen communities to alleviate poverty pang.
\end{abstract}

Keywords: Economy; Ecology; Subsidies; Poverty; Fishing policies

\section{Introduction}

The manifestations of the disregard to the coastal and marine environment are already obvious, as evidenced by the frequent reports on water shortage, polluted rivers and seas, decrease in fisheries commodities, decline of aesthetic values in water-based recreational areas and decrease in biodiversity [1]. Various laws and regulations have not been able to deter some of these ecosystems from being continually exploited on unsustainable basis.
Andhra Pradesh State is having significant and most productive agricultural land in the country, a long coastline with aquaculture potential, significant mining and offshore oil and gas reserves, moderate levels of human development, significant entrepreneurial groups, moderately well-developed road and rail infrastructure, growing concentration of industrial activity, considerable potential for renewable energy development, and a large and prosperous Diaspora.

The traditional coastal communities of Andhra Pradesh are facing pressure from the land and the depletion of the ocean ecosystem. In particular, the coastal communities at Prakasam district are over burdened with problems of poverty, unfair competition from trawlers, lack of security, unpredictable natural disasters, scarcity of drinking water, industrial pollution and so on. Vodarevu $\left(15.8136^{\circ} \mathrm{N}, 80.3547^{\circ} \mathrm{E}\right)$ marine fishing community is one of the suffering communities with poverty and pollution pangs in Andhra Pradesh situated at $7 \mathrm{kms}$ away from Chirala town. In the Vodarevu, majority of the people belong to the Vada Balija caste, but of course, this community includes several small portion of heterogeneous mixture of people from other castes like Pattapu, pallikarulu and matyakarulu. It is a very rare case in Prakasam district to observe the co-existence of marine fishing castes for livelihoods. This kind of collective effort and mutual understandings of their traditional systems are protecting them from fall. It should also be note that this community consist of both fishing and non-fishing groups together that cooperate and coordinate with each other in daily life, while the livelihood of fisheries is threatened in many ways.

\section{Social policy objective}

Fish is a highly perishable food, requiring proper handling and processing, if it is to be utilized in a cost-effective and efficient way for the benefit of those who rely on it for nutrition or income. FAO 2004 [2] estimates that up to $20 \mathrm{mn}$ tonnes of fish are wasted by being discarded at sea immediately after being 
caught. Globally, the demand for fish is growing, whereas many natural fisheries are already heavily exploited or overexploited.

Improving the welfare of coastal fishers is an important social policy objective, some of the schemes such as fuel, boat and gear subsidies, may be encouraging participants to remain in a subsector that is already highly overcapitalised. Education levels tend to be low, making it difficult for fishers to take advantage of alternative employment opportunities in the expanding national economy.

Fishermen belong to the socially and economically weaker section of the population. The fishing villages are to a large extent geographically isolated: adequate infrastructure facilities, proper road communication and sufficient fresh water supplies are lacking. The living standards of fishing community are extremely poor compared to any other caste. They have to fight for their livelihood throughout the year. A majority of fishing families (97.3\%) especially from coastal Andhra are living Below Poverty Line (BPL) compared to any other Caste in India.

Indian Government indirectly contributes towards the continued poverty and oppression of low castes and non-Hindus by 'masking' traditional discrimination. Robert Deliége [3-6] has studied the 'untouchable' communities of India extensively and states that the future of untouchables (and the poor in general) does not look encouraging and that policies such as 'positive discrimination' have accentuated caste differences [7], resulted in violence [8] but has contributed towards the 'caste' becoming a political force $[6,9]$. The proposed gains in equality are still uncertain $[10,11]$.

"Both men and women struggled in the village, but the women, because of their gender, struggled and suffered twice as much as the men." [12]

The relatively unrepresentative role of women in the Panchayat [13], and the exclusion of women from traditional institutions [13-16] and even the newly created participatory institutions $[17,18]$ has contributed to maintaining the role of women as 'second class citizens' in rural village life.

\section{Poverty and Vulnerability}

"Poverty is essentially a static concept; in contrast, vulnerability is more dynamic, capturing the multi-dimensional aspects of socioeconomic status" [19].

Vulnerability is considered to be closely linked to asset ownership; the more assets people have the less vulnerable they are [20-24]. There are strong linkages between poverty and vulnerability, in spite of this poverty is not always the predominate factor in determining levels of vulnerability but can reinforce some of the other factors [25].

Poor and unorganized people do not have a chance for political representation unless their interests can become a weapon in the struggles of the professional political field [26]. The politicization of poverty is necessary for the empowerment of the poor. Making poverty a public, moral, and political issue is often the basis upon which the poor gain leverage by making power work to their advantage through enrolling elite interests, through pro-poor coalitions, and from competition between elite groups [27]. This view of political representation argues against both interest group economism zero-sum view of structurally opposed interests dividing up the power cake (ibid), and voluntaristic approaches to empowerment through capacity building.

The integration of empowerment in poverty analysis is hindered, however, by the difficulty of measuring and monitoring progress towards empowerment [28]. Unless empowerment is measured, it is impossible to draw useful conclusions regarding the relationship or correlation between empowerment levels and poverty reduction, or the outcomes of strategies designed to empower individuals and groups [29].

To develop implementable and realistic policy options, donor agencies must understand the political context of the environments they work in (whether national, international, or local). There is a persistent sense that the emergence of poverty as an issue in formal political arenas-and of categories of the poor as politicians' constituencies-is a key feature of situations where rapid pro-poor change is likely to happen. Development agencies have little control over emerging political projects that create incentives for political participation among hitherto excluded populations. But it is helpful to have the capacity to analyze such processes and recognize where the potential for transformational change may be located.

"Institutions matter because they determine who is included or excluded and because they define the differing domains of control in state-society-community relations" [30]

\section{Role of NGO}

With many Southern NGOs having a high reliance on official aid and foreign sources, it is important for the donor agencies to find NGOs that they feel show accountability to the recipients of aid. The initiatives of NGOs can be restricted at the grassroots level if they fall into conflict with people who control the local political economies. Consequently, the success of a NGO will depend has much on their relationship with the local power structures than the suitability of their initiatives [15,31]. The work of some NGOs may be viewed with scepticism by the local power holders, especially on the back of experiences in the early 1980 's when some NGOs in India promoted social activism and civil rights as an alternative to providing economic resources $[32,33]$. Likewise, this attitude is one that can prevail at the highest levels of Government. The Foreign Exchange Management Act (FEMA) has been introduced which restricts the receipt of foreign funds for development projects to Indian NGOs. Some representatives of Non-Governmental Organisations (NGOs) and voluntary bodies feel that the Government is attempting to choke the voluntary sector by tightening the flow of foreign funds for development projects in the country (The Hindu 2002c).

"NGOs may be assumed to be less bureaucratic, wasteful or corrupt than governments, but under scrutinised groups can suffer from the same chieffailing, they can get into bad ways because they are not accountable to anyone." [34] 
Multiple violations such as deforestation, illegal constructions, sand mining, private encroachments of coasts and government apathy are leading to the destruction of some of the best sites of marine ecosystems in the study area, which is a cause of concern for environmentalists. The regressive and aggressive nature of people in Andhra Pradesh State in the recent times is not only challenging the democratic life of thousands of peace-loving innocent people but also inspiring unsolvable, unending, unnecessary debate/conflicts. Poaching of fish is turned as an international problem now. It is seriously threatening the livelihoods of fishing communities at local, regional, state, national and international levels. This is only because of irrationality and obscurity in the marine policies in the country. Small scale fisheries groups are the most vulnerable and are almost isolated due to the heavy competitiveness among the fishing communities, facing severe poverty. Vodarevu is one of this kinds facing poverty problem.

\section{Study Area and Methodology}

\section{Study area}

Andhra Pradesh State (A.P.), with $974 \mathrm{~km}$ of coastline covering 9 coastal districts namely, Srikakulam (north), Vizianagaram, Visakhapatnam, East Godavari, West Godavari, Krishna, Guntur, Prakasam, Nellore (south), situated between $13^{\circ} \mathrm{N}$ and $20^{\circ} \mathrm{N}$. Length of marine coast line - $974 \mathrm{~km}$, continental Shelf - 33,227 sq. km., No. of Fish landing centres -353 , No. of fishing villages - 555, No. of fishermen families - 1,63,427, fisherfolk population - 605,428, stands 5th in the marine fish production among the maritime states of India. The study area covers entire coast of Andhra Pradesh in general, case study method in specific by selecting marine fishing community at Prakasam District namely Vodarevu Village (figure 1).

Poverty elimination and resolving the bitter conflicts among the fisher communities is a global challenge. There is an urgent need to safeguard the marine fisher and conserve the dwindling coastal and marine ecosystem. Issues related to how social institutions interact, who possesses social networks with whom, and how factors such as social status, caste, gender and affiliations with political parties can influence factors such as levels of poverty, individual and social resilience, power and exclusion/marginalisation and overall levels of vulnerability are all key to this analysis.

\section{Methodology}

The method employed in this research is the case study method, which is a method of research that examines the poverty problems that are faced by the local Vodarevu marine fishing community in specific, fishery policies, schemes and its implementation at local level. In addition, research using the case study method to carry out exploratory and diagnostic functions in order to identify the causes of the poverty levels among the marine fishing community in Vodarevu Village at Prakasam District, viewed from socio-cultural perspective. Living experience and nature interpretations were also used to understand the empathetic conditions of the fishermen to solve the problems.

\section{Research Materials and Instruments}

Materials and instruments used to examine the livelihood conditions of marine fishing community in Vodarevu at Prakasam district include writing tools, field observations, questionnaire and a camera. The data and information collected in this research include primary data, secondary data and some previous research on the same related topic. For the purpose of data and information confirmation, a direct observation was carried out using the materials and instruments mentioned above.

\section{The Variables Examined}

The variables examined in research include the Budget allocation to the state, fishing Policies, Government Schemes, and Poverty levels at study area.

\section{Research Framework}

In this research there was a stage-wise process of research framework is given (figure 2).

\section{Data Collection Technique}

In general, the data collection techniques used in this research is field observation, lived experiences, interview, and secondary data collection (Triangulation approach). Field observation is carried out by directly observing the object of the research on account of the confirmation of the data obtained from the secondary data. The interviews are conducted by direct discussions with community elders, members, government officials, local politicians, school teachers in the study area who have a good understanding about the situation and the social issues surroundings the coastal environment by using a list of pre-selected questions. The secondary data are collected by


Figure 1: Showing the Indian Map \& Andhra Pradesh State with Districts and a Study area - Vodarevu Village at Prakasam District.



Figure 2: Flowchart of stages in the research process of the Poverty Problem Identification in Marine fisheries. 
directly visiting institutions involved, data identification, data collection and data multiplication, as well as internet research daily news events and other source.

\section{Poverty Cycle: Marine Fishing Livelihood}

\section{Poverty in marine fishery: At State Level}

Despites the facts that fisheries sector contributed significantly to economic growth and livelihood support to millions in our country, fisheries especially from Andhra Pradesh remain as poor and struggling to sustain life. Poverty in fishing communities is determined by the ownership of production tools (boat, nets etc.). Obviously, those who cannot afford to invest in productive assets and hence work on others' boats find themselves having little say in fishing operations or sharing patterns.

In India, $60.57 \%$ of the fishermen families were under BPL category as per CMFRI (2010) reports. Whereas, situation of fisheries is worst and all fishing families in coastal Andhra Pradesh are under BPL except some employees and mechanized boat owners. In Andhra Pradesh, 97.3\% of marine families were under BPL category as per CMFRI (2010) reports. Out of 1,63,427 marine fishing families in coastal Andhra Pradesh, 1,59,101 families are under BPL.

Illiteracy, lack of infrastructure, unemployment, low living standards and poor implementation of welfare schemes are the important issues to be addressed by the government to eradicate poverty in Andhra Pradesh. The poverty cycle is given (figure 3).

Table 1 clearly explains status of Andhra marine fisheries compared to other states. While Gujarat and Maharashtra states have very less percentage of marine families under BPL, percentage is extremely high in coastal Andhra Pradesh accounted nearly $30 \%$ of total BPL marine families in India.

Most of the people are illiterate and they don't have any idea of schemes introduced by government. The elders of the fisheries community are unaware of many welfare schemes introduced by central government.

\section{Fish lean time financial aid}

Seventy three thousand fishermen applied for financial aid of Rs. 4000/- during 61 days fish ban period in the year from $15^{\text {th }}$ April to $15^{\text {th }}$ June, 2016, was not given to the fishermen and moreover asking to buy a cell phone, bank account, biometric card. Government of India released only 24 crores instead of 29.20. With this amount only sixty thousand fishermen were able to benefit. It is improper if the government is asking the fishermen to maintain the above said things with them which is almost Rs. 4000/-, it leads to no gain but only pain situation.

\section{Poverty in marine fishery: At District Level}

Unpaid subsidized amount of Rs. 4 crores to the marine fishermen at Prakasam district is a mere ignorance and inactiveness of the Government officials at fisheries department. Since from three years government released subsidies fund was not distributed to the fishermen and not given unit (Table 2).

\section{Poverty in marine fishery: At Village Level}

The selected fishing village Vodarevu harbour is $7 \mathrm{kms}$ away from chirala town, Prakasam district, Andhra Pradesh. There are 42 mechanized boats ( 12 to 20 lakh cost). Every time 5 to 8 fishermen travel for fishing in these boats. There is advanced facilities in the boats. These travel 100-150 kms distance daily about $70 \mathrm{kms}$ from coast. There are 300 fiber boats travelled

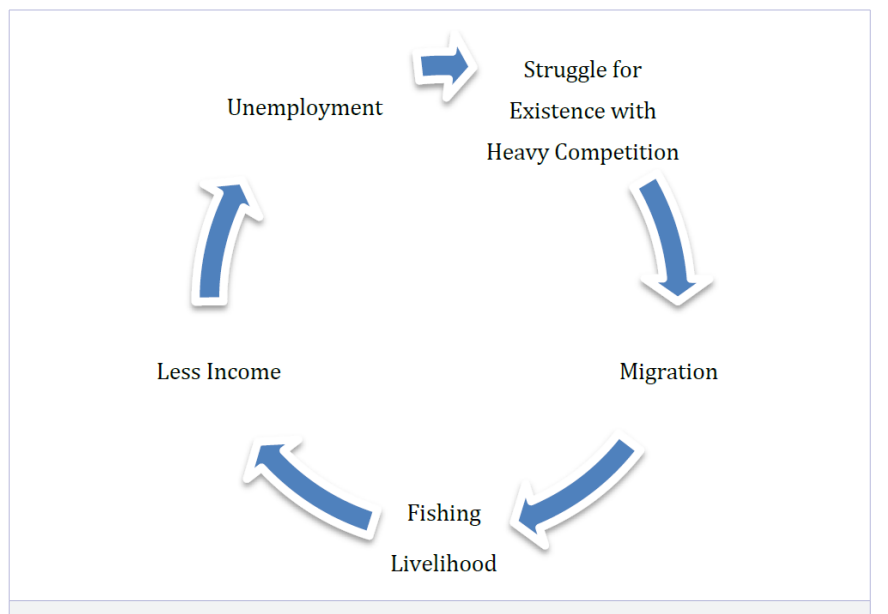

Figure 3: Poverty Cycle of fisheries in the state of Andhra Pradesh

Table 1: CMFRI, National Marine Fisheries Census, 2010: \% of BPL families in Marine states.

\begin{tabular}{|l|l|l|}
\hline S No & State & $\begin{array}{l}\text { \% of Marine families under Below } \\
\text { Poverty Line (BPL) }\end{array}$ \\
\hline 1 & West Bengal & $63.4 \%$ \\
\hline 2 & Orissa & $49.2 \%$ \\
\hline 3 & Andhra Pradesh & $\mathbf{9 7 . 3 \%}$ \\
\hline 4 & Tamil Nadu & $66 \%$ \\
\hline 5 & Gujarat & $25.3 \%$ \\
\hline 6 & Kerala & $56.2 \%$ \\
\hline 7 & Maharashtra & $19.0 \%$ \\
\hline Source: CMFRI, National Marine Fisheries Census, 2010
\end{tabular}

Table 2: the subsidy amount unpaid to the fishermen by the District Department of Fisheries at Prakasam District and DD amount taken by the fishermen.

\begin{tabular}{|l|ll|l|l|}
\hline S No & Fishing item & $\begin{array}{l}\text { Subsidy amount } \\
\text { Unpaid to } \\
\text { Fishermen by Govt. }\end{array}$ & $\begin{array}{l}\text { DD amount taken } \\
\text { by Fishermen at } \\
\text { Prakasam District }\end{array}$ \\
\hline 1 & $\begin{array}{l}\text { Big nets } \\
\text { fishermen })\end{array}$ & $(61$ & Rs. $1,00,000 /-$ & Rs. 1,00,000/- \\
\hline 2 & $\begin{array}{l}\text { OBM engine } \\
\text { fishermen })\end{array}$ & $(282$ & Rs. $27,410 /-$ & Rs. $27,410 /-$ \\
\hline 3 & $\begin{array}{l}\text { Small nets } \\
\text { fishermen })\end{array}$ & $(60$ & Rs. $7,500 /-$ & Rs. 7,500/- \\
\hline 4 & $\begin{array}{l}\text { Spreading net } \\
\text { fishermen })\end{array}$ & $(25$ & Rs. $5,000 /-$ & Rs. $5,000 /-$ \\
\hline 5 & $\begin{array}{l}\text { TVS moped } \\
\text { fishermen })\end{array}$ & $(50$ & Rs. $30,000 /-$ & Rs. $10,000 /-$ \\
\hline
\end{tabular}


by 6 members for 3 to 4 days. These boats are manufactured at Vodarevu. Nets are $2 \mathrm{kms}, 3 \mathrm{kms}$ etc. Cost of the nets from 30,000 to $40,000 /-$. The Vodarevu Fishermen community is a heterogeneous mixture of Voda balija with 2000 people in number, Pallikarulu with 500 people, Matyakarulu with 2500 people and Patapukapulu with 150 people lived together and work together without any discrimination among themselves. The total number of votes in Vodarevu is 4811, there are approximately 3000 families are residing over there. All are facing severe poverty threat. The fishermen in Vodarevu village belong to Backward Caste (BCs). The entire community is suffering from severe poverty lines. The community is lack of proper water supply, Electricity, Transportation, medical and security services. Mostly polluted by plastic goods, glassware etc. The $10 \mathrm{kms}$ road is constructed recently by the central government under Prime Minister Project passing through the village, caused loss of biodiversity and ecocidal in its usage. More alcoholic distribution and consumption is taking place by the tourists. The sand mafia, crime rate increased in the recent years. There are no alternative livelihood resources.

If the village does not function properly, the state will not function, if the state does not function properly, the nation will not function, if the nation does not function properly, the global community will not function.

\section{Results and Discussion}

The results in the study show that the $99 \%$ of the village dwellers are facing severe poverty problems. At least, they are unable to produce livelihood for last three years because of extended fish ban period, lean period, government's untimely subsidies and financial support that they are getting. The fishing village is one of the oldest forms of social organization, based on a lifestyle that reflects a special relationship between humans and the ocean. Fishing is an informal sub-sector operated by the illiterate traditional fishermen but supervised by the formal sector. Hence, this sub-sector should be comprehensive, consistent, trans-sectoral or multidisciplinary, participational and bottom-up rather than top-down. Because fishing is the main occupation of many coastal people; it is the only source of income for most of them. But every day they cannot go to the sea for fishing, during rainy season it is very risky to get into the sea, since fishermen do not have any other way to earn money, they have to go into the sea as often as possible and they don't get proper support from the government. They have been several instances where fishermen have dared to get into sea in dangerous circumstances and landed up losing their lives, most of them were found to not even have any insurance policy leaving their family members without any source of income.

Figure 4 shows that until so far fish governance was operated from top down mechanism which generated more poverty problem to the traditional and small scale fishermen. This top down approach from global to village level. Whereas, in the bottom up governance mechanism from local village level to the global level the outcome may be sustainable. Following Gandhi's vision of the oceanic circle, we can project a global social order originating from the individual through the village and the community of villages, where the outermost circumference will not wield power to crush the inner circle but will give strength to it and will also derive from this, its own strength.

Fishing is most continued as an inherited family or community profession, people get the experience of fishing in their childhood itself, so they do not generally think about going for higher education and going for a dignified job. In childhood and in young age, their profession would help them to get good pocket money. But when they have the responsibility of managing their family ,the income from fishing doesn't help them much, at that time they realize about the difficulty in their profession, but by then, it is too late for them of shifting on to other profession, so the government should bring the measure to solve the problems of fishermen they have to be given some job to lead their life during the dangerous times, it would help them to not go into the sea, during times when the tides are high and can be dangerous for their lives, government should also give them insurance coverage, the more $100 \%$ risk is fishing and they will protect the life of the dependents upon the death of fishermen so that his family is not left stranded, absolute poverty is the principle cause of misery today among fishermen.

A condition of a fishermen life so characterized by low life expectancy, meagre existence living in secluded and far-flung coastal areas, caste occupation and poverty ridden trap and living in constant lack of hope as to beneath any reasonable definition of human decency and dignity, fishermen still suffer all degradation and humiliation, they are the living monuments of social backwardness and utter poverty.

\section{Discrimination in Budget allocation By Central Government}

Andhra Pradesh State is one of the most disastrous in Southasia with $974 \mathrm{kms}$ of coastline. Within the last 100 years, Andhra Pradesh State experienced 110 cyclones. In the last 10 years, Andhra Pradesh State lost Rs. 1,45,000 crores due to the natural calamities. National Disaster Relief Fund (NDRF) (Table 3) should be based on the Coastline, disasters, natural calamities, drought proven regions etc. But due to the discrimination in the allocation of NDMF Andhra Pradesh state was allocated with only Rs. 440 crores.

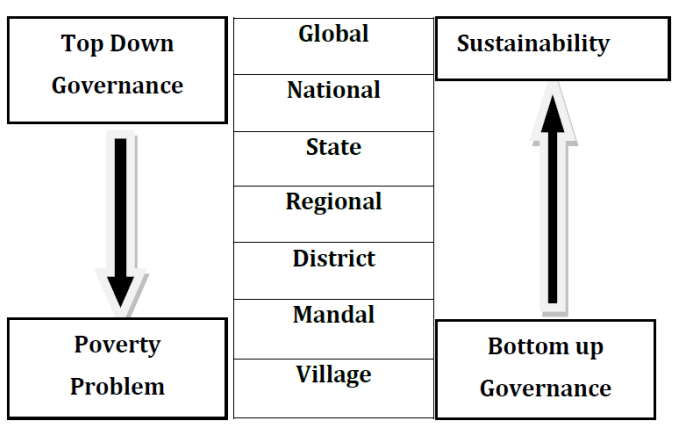

Figure 4: Fisheries Governance from top down \& bottom up 
Table 3: National Disaster Relief Fund (NDRF) announced for the Coastal states: 2015-2020.

\begin{tabular}{|l|l|l|l|}
\hline S No & States & Coastline & $\begin{array}{l}\text { Allocated NDM Fund } \\
\text { (2015-2020) }\end{array}$ \\
\hline 1 & Gujarat & $1600 \mathrm{kms}$ & Rs. 3894 crores \\
\hline 2 & Kerala & $1014 \mathrm{kms}$ & Rs. 1022 crores \\
\hline 3 & $\begin{array}{l}\text { Andhra } \\
\text { Pradesh }\end{array}$ & $\mathbf{9 7 4} \mathbf{k m s}$ & Rs. 2430 crores \\
\hline 4 & West Bengal & $950 \mathrm{kms}$ & Rs. 2853 crores \\
\hline 5 & Maharastra & $840 \mathrm{kms}$ & Rs. 8195 crores \\
\hline 6 & Tamilnadu & $720 \mathrm{kms}$ & Rs. 3751 crores \\
\hline 7 & Odisha & $560 \mathrm{kms}$ & Rs. 4130 crores \\
\hline
\end{tabular}

The politically driven welfare policies of Governments elucidate that the ruined fishermen due to the debts to benefit wealthier middlemen as well. This view of empowerment can be critiqued because of an underlying assumption that public servants are typically self-serving, rather than altruistic [36]. Many problems, which cannot be solved in a large-scale context, can, instead, be solved at the level of the local community. The small community facilitates forms of direct democracy, with the full participation of all stakeholders; it is easier to create a sense of individual and collective responsibility, a feeling of commonality of interests. The ocean is both benign, a provider of food, and antagonistic, a destroyer of human life or even of the village in its entirety. The human being is so small and helpless in confronting the mighty ocean in fear, awe, reverence, if also in a spirit of mythmaking and superstition. To face this ocean, fishing activities have to be co-operative, not competitive, and the distribution of the common resource has to be equitable, for were it not, co-operation would disintegrate.

A de-politicized view of empowerment can lead to donor agencies engaging in capacity-building activities that may reinforce power relations that are unfavourable to many poor people. A common resource, co-operatively managed and equitably distributed, will not be destroyed, whether by overfishing, which is a consequence of competition, or by pollution, which is a waste. Wisdom, accumulated by the village through centuries or even millennia, will inspire self-regulation to prevent both. Fishing, on which the fishing village depends, is not the only activity required for the sustainability of the village.

Moreover, most of the government schemes are confined to the papers only because of the government's tendency to initiate schemes without setting aside enough funds to successfully implement them, thereby almost willing them to failure. The more the number of schemes, the greater is the likelihood of inefficiency. Interests of national elites and the electoral concerns of those in power affect the state's policy choices, sector priorities, and programs, with important consequences for the poor. Equally, well-intentioned sector reform programs can run aground where they challenge vested interests, and democratic reforms often have limited or unpredictable effect on power relations. And where local elites are well placed to capture benefits and reservations (in education, employment, or for elections), or to manipulate the administrative system upon which the poor depend for their livelihood and for access to anti-poverty schemes, formal processes of decentralization may do little to reduce informal forces of domination [37]. people become empowered not in themselves, but through relationships with outsiders; and not through the validation of their existing knowledge and actions, but by seeking out and acknowledging the superiority of modern technology and lifestyles, and by aligning themselves with dominant cultural forms" [38,39].

\section{Conclusion}

Poverty reduction at state, district as well as village is an essential requirement that needs immediate concentration by the Governments. Fishing policies should be eco-friendly and fishermen-centric rather than for economic growth of the country. The State as well as Central Government must provide necessary funds to the marine fishing communities in the state of Andhra Pradesh. Moreover, most of the Government Schemes should not be confined to the papers. The Structured fishing practices at coast will be promoted to safeguard the coastal as well as marine ecosystems. The poverty alleviation programmes of both the GOs \& NGOs must ensure that the enhancement of fishermen-centric policies and schemes by safeguarding the environment. The fishing communities based on the gears that were used, ultimately leading to the depletion of fish by overfishing. Discrimination in budget allocation to the vulnerable as well as disaster proven regions of the country is one of the major problems in India. Poverty is also an unavoidable and undesirable qualification of Indian masses, directly or indirectly leading to many other problems. The lived experience of marine fishermen communities at Prakasam district in Andhra Pradesh reveals that the politically driven welfare policies of Governments are working towards the country's economic growth rather than to safeguard the fishermen communities to alleviate poverty pang. Hence, it is concluded that illiteracy, lack of infrastructure, unemployment, low living standards and poor implementation of welfare schemes are the important issues to be addressed by the government to eradicate poverty in Vodarevu as well as in the entire state of Andhra Pradesh.

\section{References}

1. Yusoff FM, Shariff M, Gopinath N. Diversity of Malaysian aquatic ecosystems and resources. Aquatic Ecosystem Health and Management. 2006;9(2):119-135.

2. FAO. The State of World Fisheries and Aquaculture, Food and Agriculture Organization, Rome. 2004;153.

3. Deliége R. Les Paraiyars du Tamil Nadu. Nettetal, Steyler Verlag. 1988.

4. Deliége R. Replication and Consensus: Untouchability, Caste and Ideology in India. Man (n.s.). 1992;27:155-17.

5. Deliége R. The Myths of Origin of the Indian Untouchables. Man (N.S.). 1993;28:533-49.

6. Deliége R. The Untouchables of India, Oxford, Berg. 1999.

7. Srinivas MN. Caste in Modern India and other Essays. Asia Publishing House, London. 1962.

8. Yagnik A, Bhatt A. The anti-Dalit Agitation in Gujarat. South Asia Bulletin, IV, 1, Spring. 1984;48. 
9. Beteille Andre. Society and Politics in India: Essays in a Comparative Perspective. London: Athlone Press. 1991.

10. Upadhyaya KK. The Political Economy of Reservations in Public Jobs in India: Implications for Efficiency in Public Administration and Equity in Society. International Journal of Social Economics. 1998;25:10491063.

11. Mendelsohn O, Vicziany M. The Untouchables: Subordination, Poverty and the State in Modern India, New York, Cambridge University Press. 1998.

12. Bumiller E. May You Be the Mother of a Hundred Sons. New Delhi. Penguin Books. 1991.

13. Moore EP. Gender, Law and Resistance in India. Tucson, AZ: University of Arizona Press. 1998.

14. Agarwal B. Participatory Exclusions, Community Forestry, and Gender: An Analysis for South Asia and a Conceptual Framework. World Development. 2001;29(10):1623-1648.

15. Beck T. The Green Revolution and Poverty in India: A Case Study of West Bengal. Applied Geography. 1995;15(2):161-81.

16. Robbins P. The Rotten Institution: Corruption in Natural Resource Management. Political Geography. 2000;19(4):423-43.

17. Agarwal B. Environmental Action, Gender Equity and Women's Participation. Development and Change. 1997;28(1):1-44.

18. Deepa N, Schafft K, Rademacher A. Koch-Schulte S. Voices of the Poor: Can Anyone Hear Us? m New York, Oxford University Press. 2000.

19. Moser C. Mcllwaine C. Household Responses to Poverty \& Vulnerability: Volume 3: Confronting Crisis in Commonwealth, Metro Manila, the Philippines. Urban Management Programme Publication No.23, Washington DC, the World Bank. 1997.

20. Sen A. Poverty and Famines: An Essay on Entitlement and Deprivation. Oxford: Clarendon Press. 1981

21. Swift J. Why are rural People Vulnerable to Famine? IDS Bulletin. 1989;20(2)

22.World Bank. The World Bank annual report 1990. Washington, DC: The World Bank. 1990. http://documents.worldbank.org/curated/ en/562761468762881153/The-World-Bank-annual-report-1990 .

23. Putnam R. The Prosperous Community: Social Capital and Public Life. The American Prospect. 1993;13. a

24. Putnam RD, Leonardi R, Nanetti RY. Making Democracy Work: Civic Traditions in Modern Italy. Princeton, Princeton University Press. 1993.
25. Chambers R. Rural Development: Putting the Last First. Harlow, Longman. 1983.

26. Bourdieu Pierre. Language and symbolic power. Ed. John B. Th ompson, trans. Gino Raymond and Matthew Adamson. Cambridge: Polity Press. 1991.

27. Moore M, James Putzel. Thinking strategically about politics and poverty. IDS Working Paper 101. Brighton: Institute of Development Studies. 1999

28. Grootaert C. Assessing empowerment in the ECA region. Paper presented at the Measuring Empowerment: Cross-Disciplinary Perspectives workshop. Washington, DC: World Bank. 2003.

29. Strandberg N. Conceptualising empowerment as a transformative strategy for poverty eradication and the implications for measuring progress. 2002. Available at: http://www.un.org/womenwatch/daw/ csw/empower/documents/Strandberg-EP6.pdf

30. Davies S, Hossain M. Livelihood Adaptation, Public Action and Civil Society: A Review of the Literature, IDS Working Paper 57, Brighton, Institute of Development Studies. 1997.

31. Hartmann B, Boyce JK. A Quiet Violence: A View from a Bangladesh Village. Zed Press, London. 1983.

32. Sheth DL. Alternative developments as political practice. Alternatives. 1987;12:155-71.

33. Lewis P. Social Action and the Labouring Poor: an experience. Vistar Publications, Delhi. 1991.

34. The Economist. Sins of the secular missionaries, an excerpted article from The Economist: January 29, 2000.

35. CMFRI. National Marine Fisheries Census, 2010.

36. Le Grand Julian. Motivation, agency and public policy: Of knights and knaves, pawns and queens. Oxford, UK: Oxford University Press. 2003

37. Jenkins Rob. Domestic politics and the WTO. Presentation for ODI/ DESTIN conference Putting Politics Back into Development: Are We Getting There? London. 2002.

38. Mosse David. Adivasi migrant labour support: A collaborative programme,

consultant's report 2004 a. Cultivating development: An Ethnography of aid policy and practice. London: Pluto. 2002.

39. Fiedrich Marc. Domesticating Modernity: Understanding Women's Aspirations in Participatory Literacy Programmes in Uganda. PhD diss., University of Sussex. 2002. 